\title{
PEMIKIRAN IBNU MISKAWAIH (RELIGIUS-RASIONAL) TENTANG PENDIDIKAN DAN RELEVANSINYA DI ERA INDSUTRI 4.0
}

\author{
Alimatus Sa'adah ${ }^{1}$, M. Farhan Hariadi ${ }^{2}$ \\ 1,2 Pascasarjana UIN Sunan Kalijaga Yogyakarta \\ ${ }^{1}$ Email: alimablue8@gmail.com \\ 22Email: Farhanhariady777@gmail.com
}

\begin{abstract}
Abstrak: Tujuan kajian ini adalah membahas tentang pemikiran seoarang filosuf muslim yang Ibnu Miskawaih tentang pendidikan dan relevansinya di era revolusi industri 4.0 ini. Ibnu Miskawih adalah salah seorang filsuf muslim yang paling banyak mengkaji dan mengungkapkan persolan-persoalan akhlak. Penelitian ini merupakan penelitian kualitatif bersifat deskriptif, yakni penelitian yang menekankan pada analisis terhadap data-data yang sudah ada sebelumnya. . Jenis penelitian ini termasuk studi kepustakaan (library research), yakni serangkaian kegiatan yang berkenaan dengan metode pengumpulan data pustaka, membaca dan mencatat serta mengolah bahan penelitian. Pada bagian ini dilakukan pengkajian mengenai konsep dan teori yang digunakan berdasarkan literatur yang tersedia, terutama dari artikel-artikel yang dipublikasikan dalam berbagai jurnal ilmiah. Kajian pustaka berfungsi untuk membangun konsep atau teori yang menjadi dasar studi dalam penelitian Adapun Ibnu Miskawaih melihat begitu pentingnya arti pendidikan, konsep dan lingkungan bagi manusia untuk mempermudah proses pembinaan akhlak. Berkenaan dengan akhlak, manusia dengan akalnya dapat memilih dan membedakan apa yang seharusnya dilakukan dan apa yang harus ditinggalkan. Pemikiran Ibnu Miskawaih dalam pendidikan bertumpu pada konsep tentang manusia dan pendidikan akhlak. Di mana akhlak menjadi dasar bagi manusia untuk membentuk hubungan yang baik dengan Tuhan, alam dan manusia, apalagi di era revolusi industri 4.0 seperti sekarang ini secara tidak langsung mengakibatkan pergeseran akhlak.
\end{abstract}

Kata Kunci: Ibnu Miskawaih, Manusia, Pendidikan Akhlak

Title: Ibnu Miskawih's thoughtsabout education and its relevance in the era of the industrial revolution 4.0

Abstract: The study discusses the philoshical Muslim Ibnu Miskawih about education and its relevance in the era of the industrial revolution 4.0. This research is a descriptive qualitative research, that is the research which emphasizes the analysis of previous data. This type of research is library research, which consists of library data collection methods, reading and recording and processing research materials. In this section, a review of available literary concepts and theories is carried out, especially from articles published in various scientific journals. Literature study serves to build concepts or theories that form the basis of study in research. bnu Miskawih is one the most widely studied Muslim philoshopers and philosphers. As for Ibnu Miskawih, the importance of education, concepts anda environment is inportant bumans to facilitate the process of morale building. When it comes to morals, humans can intellectually decide what to and what to leave behind. Ibnu Miskawrih's thingking in education focuses on the concepts of buman and moral education. Where morality is the basis for man to form a good relationship with God, nature and man, let alone in the era of the industrial revolution 4.0 such as this has indirectly led to a moral shift.

Keyword: Ibnu Miskawih, Human, Moral Edaction 


\section{PENDAHULUAN}

Pendidikan adalah bagian penting dari kehidupan manusia. ${ }^{1}$ Maka dalam siklus kehidupan, manusia tidak bisa terlepas dari yang namanya pendidikan. Pendidikan memiliki peran penting karena pendidikan mempunyai andil dalam mengembangkan potensi fisikal maupun spiritual bagi seseorang atau maysarakat. Jika dilihat zaman dahulu fungsi utama pendidikan adalah pemindahan nilai-nilai seperti nilai kejujuran, setia kawan, dan lain-lain yang perlu dipelihara demi keutuhan dan kelanjutan hidup masyarakat, sebab masyarakat tanpa sebuah nilai-nilai akan hancur. ${ }^{2}$

Pendidikan merupakan suatu proses internalisasi budaya kedalam diri seseorang dan maysarakat sehingga membuatnya menjadi beradab atau berkahklak karimah/mulia. ${ }^{3}$ Pendidikan tidak semata hanya mentransfer pengetahuan (knowlage transfer) melainkan pendidikan menumbuh kembangkan kepribadian dan karakter yang baik. Pendidikan merupakan rangkaian proses pemberdayaan dan peningkatan potensi individu menjadi manusia yang berkualitas yang berlangsung sepanjang hayat.

Menurut Fazlur Rahman, tujuan pendidikan adalah untuk menanamkan komitmenkomitmen nilai melalui pendidikan moral dan mengomunikasikan pengetahuan ilmiah melalui pengajaran. ${ }^{4}$ Begitu pentingnya sebuah pendidikan, maka pendidikan sering dijadikan tolak ukur perkembangan dan kemajuan individu, sekelompok orang dan bahkan suatu negara. Keberhasilan pendidikan akan menciptakan individu yang beradab dan kemudian akan memunculkan kehidupan sosial yang bermoral.

Berkaitan dengan pendidikan karakter atau akhlak, seperti yang kita ketahuai terjadi fenomena sosial yang menyebabkan pemerintah untuk merumuskan kebijakan nasional pembangunan karakter bangsa. Dalam rencana pembangunan jangka panjang Nasional tahun 2005-2025 (Undang-Undang Republik Indonesia Nomor 17 Tahun 2007) menyatakan;

"terwujudnya suatu karkater bangsa yang tangguh, kompetetif, berakhlak mulia dan bermoral berdasarkan pancasila yang dicirikan dengan watak dan perilaku manusia dan maysarakat Indonesia yang beragama, beriman dan bertakwa kepada Tuhan Yang Maha Esa, berdudi luhur, bertoleran, bergotong royong, berjiwa patriotik. ${ }^{5}$

Maka dari itu pendidikan diharapkan menghasilkan insan yang berkualitas dan bertanggung jawab dan mampu mengantisipasi masa depan. Mastuhu mengungkapkan dalam

\footnotetext{
${ }^{1}$ Usman, filsafat Pendidikan Kajian Filosofi, Pendidikan Nabdlatul Wathan di Lombok, (Yogyakarta: Teras), h.1

${ }^{2}$ Hasan Langgulung, Asas-Asas Pendidikan Islam, (Jakarta: PT Al Husna Zikra, 2000), h. 402

${ }^{3}$ Maimun, Menjadi Guru Yang Di rindukan (Pelita Yang Menerangi Jalan Hidup Siswa), (Yogyakarta; Kurnia Kalam Semesta,2014), h.151

${ }^{4}$ Fazlur Rahman, Islam and Modernity, Transformasi of an Intellectual Tradition. Diterjemahkan oleh Ahsin Mohamma. (Bandung: Pustaka, 1985) hlm 62

${ }^{5}$ Rusmaini, "Manajemen Pendidikan Karakter di Lembaga Pendidikan Islam", Jurnal Of Islamic Education Management .3, no.1 (Juni, 2017), h.134
} 
saliminawati bahwa manusia adalah makhluk yang senantiasa membutuhkan pendidikan karena manusia dibekali potensi yang dinamis dan harus dikembangkan yaitu melalui pendidikan. ${ }^{6}$

Sejalan dengan uraian di atas dimana di Era industri 4.0 sekarang ini, jika kita telisik lebih dalam begitu banyak perubahan dalam menjalani kehidupan ini sehingga tidak dipungkiri terjadi degradasi moral. ${ }^{7}$ Di era Revolusi Indutri 4.0 juga saat ini dimana teknologi dan informasi berkembang pesat dan tidak dipungkiri selain memiliki dampak positif juga akan berdampak negatif terhadap dunia pendidikan seperti tergesernya akhlak yang terjadi dalam dunia pendidikan. Di era yang serba canggih saat ini semua bisa didapatkan dengan mudah dan cepat, seperti halnya dalam pendidikan, siswa maupun guru dapat belajar melalui media massa, gadjetnya ataupun secara online. Akan tetapi hal tersebut tidak terlepas dari dampak negaif seperti yang sering terjadi, tidak sedikit siswa berkasus terkait sexsual, kekerasan/tawuran bahkan melawan gurunya sendiri sehingga jati diri pendidikan yang menghasilkan peserta didik yang berakhlak mulia, mandiri, tanggung jawab, dan berprestasi kurang maksimal.

Berkaitan uraian di atas, dalam kajian ini penulis akan memaparkan bagaimana sumbangsih pemikirian seorang tokoh pendidikan sekaligus seorang ulama yang sesuai dengan konteks Indonesia, pemikiran Ibnu Miskawaih yang memandang penting pendidikan akhlak yang bisa membawa manusia pada kebaikan dan kebahagiaan. Akhlak yang di bentuk melalui pendidikan harus disadari oleh setiap kalangan, agar tercipta tujuan pendidikan yang diharapkan membawa pembaharuan di era revolusi industri 4.0 sekarang ini.

\section{METODE PENELITIAN}

Penelitian ini merupakan penelitian kualitatif bersifat deskriptif ${ }^{8}$, yakni penelitian yang menekankan pada analisis terhadap data-data yang sudah ada sebelumnya. Dalam penelitian ini, peneliti mengumpulkan informasi yang berhubungan dengan pemikiran Ibnu Miskawaih terkait dengan Pendidikan dan relevansinya pada era industry 4.0 serta pemikiran atau ide berkaitan dengannya. Jenis penelitian ini termasuk studi kepustakaan (library research), yakni serangkaian kegiatan yang berkenaan dengan metode pengumpulan data pustaka, membaca dan mencatat serta mengolah bahan penelitian. Pada bagian ini dilakukan pengkajian mengenai konsep dan teori yang digunakan berdasarkan literatur yang tersedia, terutama dari

${ }^{6}$ Ibrahim Sirat, Dja'far Siddik, Siti Zubaidah, "Implementasi Pendidikan Akhlak Dalam Pengembangan Pendidikan Karakter Di Man 1 Medan, Jurnal Edu Religia 1, no.4, (Desember 2017), h. 549

7 Dian Arif Noor Pratama, "Tantangan Karakter Di Era Revolusi Industri 4.0 Dalam Membentuk Kepribadian Muslim”, Al-Tanzim: Jurnal Manajemen Pendidikan Islam 03, no.01, h. 21

8 Anwar Sanusi, Metodologi Penelitian Bisnis, (Jakarta: Salemba Empat,2016), h.13 
artikel-artikel yang dipublikasikan dalam berbagai jurnal ilmiah. Kajian pustaka berfungsi untuk membangun konsep atau teori yang menjadi dasar studi dalam penelitian. ${ }^{9}$

Kajian pustaka pada umumnya berisi tentang uraian tentang teori, temuan dan bahan penelitian lain yang diperoleh dari bahan acuan untuk dijadikan landasan kegiatan penelitian. Uraian dalam literature review ini diarahkan untuk menyusun kerangka pemikiran yang jelas tentang pemecahan masalah yang sudah diuraikan sebelumnya pada perumusan masalah. Penelitian dimulai dengan penelusuran pustaka yang berhubungan dengan subyek penelitian. Penelusuran pustaka merupakan langkah-langkah untuk mengumpulkan informasi yang relevan bagi penelitian.

\section{TEMUAN DAN PEMBAHASAN}

\section{Sketsa Biografi Ibnu Miskawaih (320-421 H)}

Nama lengkap Ibnu Miskawai adalah Abu Ali al-Khazin Ahmad Ibn Muhammad Ibnu Ya'qub Ibn Miskawaih. Dilahirkan tahun 320 H/ 932 M dan wafat pada tahun 412 H/ 1030 M. Aktivitas intelektual Ibnu Miskawaih dimulai dengan belajar sejarah kepada Abu Bakr Ahmad Ibn Kamil al-Qadhi. Kemudian beliau belajar filsafat kepada Ibn al-Khammar. Disamping itu beliau juga belajar kimia darii Abi al-Tayyibannal-Razi, seorang ahli kimia terkenal di zamannya.

Ibnu Miskawaih adalah serang ahli sejarah yang pemikirannya sangat cemerlang, beliaulah ilmuwan Islam yang paling terkenal dan yang pertama kali menulis filsafat akhlak. Beliau juga sangat memahami model administrasi dan strategi peperangan. Oleh karena itu, dalam sejarah beliau tercatat sebagai sekretaris Amirul-Umara Adhud-Daulah (949-982 M) dari daulat Buwaihi di Baghdad, merangkap kepala perpustakaan Bait al-Hikam.

Sebagai seorang yang sangat memahami filsafat akhlak, semua karya Ibnu Miskawaih tidak luput dari kepentingan filsafat akhlak. Sehubungan dengan itu, tidak heran jika Ibnu Miskawaih dikenal sebagai moralis. Abu Manshur al-Tsalabi $(421 \mathrm{H})$ menerangkan bahwa Ibnu Miskawaih adalah pribadi mulia yang penuh keutamaan, halus budi, ahli sastra, ahli balaghah, ulet dan sebagai penyair. ${ }^{10}$ Lebih lanjut Ibnu Miskawaih adalah salah seorang filsuf muslim yang menitik beratkan perhatiannya pada etika Islam. Meskipun sebenarnya iapun seorang sejarawan, tabib, ilmuwan dan sastrawan. ${ }^{11}$

Mempehatikan tahun lahir dan wafatnya, Ibnu Miskawaih hidup pada masa pemerintahan Bani Abbas yang berada di bawah pengaruh Bani Buwaih. Puncak kemegahan

\footnotetext{
${ }^{9}$ V.Wiratna Sujarweni, Metodeologi Penelitian, (Yogyakarta: Pustaka Baru Perss, 2014), h.57

${ }^{10}$ Heri Gunawan, Pendidikan Islam Kajian Teoritis dan Pemikiran Tokoh, (Bandung: Remaja Rosdakarya, 2014), h. 308

${ }_{11}$ Ahmad Azhar Basyir, Miskawaih Riwayat Hidup dan Pemikiran Filsafatnya, (Yogyakarta: Nur Cahaya, 1983), h. 1
} 
kekuasaan Bani Buwaih adalah pada masa 'Adhud Ad-Daulah yang berkuasa dari tahun 367372 M. pada masa inilah Ibnu Miskawaih memperoleh kepercayaan untuk menjadi bedaharawan, pada masa ini jugalah Ibnu Miskawaih muncul sebagai filsuf, tabib, ilmuwan dan pujangga. Tetapi di samping itu hal yang tidak menyenangkan hati Ibnu Miskawaih adalah kemerosotan moral yang melanda masyarakat. Oleh karena itulah agaknya Ibnu Miskawaih tertarik untuk menitik beratkan perhatiannya dalam bidang etika Islam.

Ibnu Miskawaih tidak mengikuti pelajaran privat, karena ekonomi keluarganya yang kurang mampu untuk mendatangkan guru, terutama untuk pelajaran-pelajaran lanjutan yang biayanya mahal. Perkembangan ilmu Ibnu Miskawaih terutama sekali diperoleh dengan jalan banyak membaca buku-buku, terutama di saat-saat memperoleh kepercayaan menguasai perpustakaan Ibn Al-'Amid, menteri Rukn Ad-Daulah, yang akhirnya memperoleh kepercayaan sebagai bendaharawan 'Adhud Ad-Daulah. ${ }^{12}$

Pengetahuan Ibnu Miskawaih yang amat menonjol dari hasil banyak membaca buku itu ialah tentang sejarah, filsafat dan sastra. Hingga saat ini nama Ibnu Miskawaih dikenal terutama sekali dalam keahliannya sebagai sejarawan dan filsuf. Sebagai filsuf, Ibnu Miskawaih memperoleh sebutan Bapak Etika Islam.

\section{Karya-Karya Ibnu Miskawih}

Sebagai seorang filsuf, sejarawan, tabib, ilmuan dan satrawan, Ibnu Miskawaih menulis banyak buku-buku dalam berbagai macam bidang keahliannya. Diantara buku-buku karangannya dapat disebutkan sebagai berikut:

1. Kitab Al-Fauz Al-Ashghar, tentang ketuhanan, jiwa dan kenabian (metafisika).

2. Kitab Al-Fauz Al-Akbar, tentang etika.

3. Kitab Thaharat An-Nafs, tentang etika.

4. Kitab Tahdzib Al-Akhlaq wa That-hir Al-A'raq, tentang etika.

5. Kitab Tartib As-Sa'adat, tentang etika dan politik, terutama mengenai pemerintahan Bani 'Abbbas dan Bani Buwaih.

6. Kitab Tajarib Al-Umam, tentang sejarah, yaitu berisi peristiwa-peristiwa sejarah sejak setelah air bah Nabi Nuh hingga masa tahun $369 \mathrm{H}$.

7. Kitab Al-Jami', tentang ketabiban.

8. Kitab Al-Adwiyah, tentang ketabiban

9. Kitab Al-Asyribah, tentang minuman.

10. Kitab Al-Mustaufi, berisi kumpulan syair-syair pilihan.

11. Kitab Jawizan Khard (Akal Abadi), membicarakan pemerintahan dan hukum.

${ }^{12}$ Ibid., h. 2-4 
12. Maqalat fi An-Nafsi wal 'Aqli, tentang jiwa dan akal. ${ }^{13}$

Dari pemaparan di atas Ibnu Miskawaih yang hidup pada masa pemerintahan Bani Abbas yang berada di bawah pengaruh Bani Buwaih merasa bahwa penurunan moral yang melanda masyarakat pada masa itu menuntutnya untuk mencurahkan pemikiran dalam bidang etika Islam agar masyarakat kembali pada akhlak seperti yang di contohkan Rosulullah SAW.

\section{Konsep Pemikiran Pendidikan Ibnu Miskawaih}

Dalam filsafat, Ibnu Miskawaih tidak memberikan pengertian-pengertiannya. Beliau hanya membagi filsafat menjadi dua bagian; bagian teori dan bagian praktik. Bagian teoritik merupakan kesempurnaan manusia yang mengisi potensinya untuk dapat mengetahui segala sesuatu, hingga dengan kesempurnaan ilmunya itu pikirannya benar, keyakinannya benar dan tidak ragu-ragu terhadap kebenaran. Sedang bagian yang praktik merupakan kesempurnaan manusia yang mengisi potensinya untuk dapat melakukan perbuatan-perbuatan moral. Akhir dari kesempurnaan moral adalah sampai dapat mengatur hubungan antar sesama manusia hingga tercipta kebahagiaan hidup bersama. Jika manusia berhasil memiliki dua bagian filsafat, yang teoritik dan yang praktik tersebut, maka berarti ia telah memperoleh kebahagiaan yang sempurna. ${ }^{14}$

Kata akhlak merupakan bentuk jamak dari al-khuluq atau al-khulq yang secara etimologi berarti: (1) tabiat, budi pekerti, (2) kebiasaan atau adat, (3) keperwiraan, kesatriaan, kejantanan, (4) agama. Al-Ghazali mendefinisikan akhlak yaitu sifat yang tertanam pada jiwa yang menimbulkan perbuatan dengan mudah tanpa memerlukan pemikiran dan pertimbangan.

Sebagaimana Rasulullah menegaskan dalam hadits bahwa "Sesunggubnya Aku diutus untuk menyempurnakan akblak mulia”. (HR. Ahmad). Dalam hadits lain juga disebutkan "Mukmin yang paling sempurna imannya adalah yang paling baik akblaknya." (HR. Tirmidzi).

Akhlak itu sesungguhnya perpaduan antara lahir dan batin. Seseorang dikatakan berakhlak apabila seirama antara perilaku lahir dan batinnya. Karena akhlak itu juga terkait dengan hati, maka pensucian hati adalah salah satu jalan untuk mencapai akhlak mulia. Dalam pandangan Islam hati yang kotor akan menghalangi seseorang mencapai akhlak mulia. Boleh jadi dia melakukan kebajikan kebajikan tetapi kebajikan yang dia lakukan itu bukanlah tergolong akhlak mulia, karena tidak dilandasi oleh hati yang mulia pula. Disinilah letak akhlak dengan etika atau moral. Pada tataran akhlak berperan ganda lahir dan batin, sedangkan etika atau moral berada pada tataran lahiriyah saja. ${ }^{15}$

\footnotetext{
13 Ibid., h. 4-5

${ }^{14}$ Ibid., h. 6-7

${ }^{15}$ Haidar Putra Daulay, Pendidikan Islam dalam Perspektif Filsafat, (Jakarta: Kencana, 2014), h. 133-134
} 
Akhlak dapat dibentuk melalui beberapa metode, yaitu: (1) Metode Ta'lim, metode ini adalah melakukan transfer ilmu kepada seseorang. Mengisi otak seseorang dengan pengetahuan yang berkenaan dengan baik dan buruk. (2) Metode Pembiasaan, metode ini merupakan kelanjutan dari metode ta'lim. Melalui pembiasaan seseorang terutama kanakkanak akan tertanam kepadanya kebiasaan baik dan menjauhi kebiasaan buruk. (3) Metode Latihan, metode ini hampir sama dengan metode pembiasaan, hanya saja sudah ada unsur paksaan dari dalam diri sendiri untuk melaksanakan perbuatn baik. (3) Metode Mujahadah, metode ini tumbuh dalam diri seseorang untuk melakukan perbuatan baik, dan dalam melakukan itu didorong oleh perjuangan batinnya. ${ }^{16}$

Pemikiran Miskawaih masih banyak yang harus dikaji, seperti metafisika, psikologi dan filsafat sosialnya. Pengkajian lebih luas dan mendalam tentang filsafat Ibnu Miskawaih akan besar faedahnya bagi kita bangsa Indonesia yang tengah melaksanakan pembangunan menuju tercapainya manusia Indonesia seutuhnya. Bahan bacaan yang amat langka di Indonesia tentang Ibnu Miskawaih perlu mendapat perhatian para ilmuan Muslim. ${ }^{17}$

Sebagai seorang filosuf akhlak, pemikiran Ibnu Miskawaih dalam pendidikan tidak bisa dilepaskan dari konsep tentang manusia dan akhlak. Maka berbicara tentang pemikiran pendidikan Ibnu Miskawaih lebih tepat jika dikaji terlebih dahulu tentang dasar pemikiran beliau yang terkait dengan tingkatan daya dan akhlak. ${ }^{18}$ Baik dari segi potensi, pendidikan akhlak, metode yang digunakan dan lingkungan. Sebagaimana dijelaskan di bawah ini sebagai berikut :

1. Tingkatan Potensi Manusia

Pandangan Ibnu Miskawaih terhadap manusia tidak jauh berbeda dengan pandangan para filsuf lainnya. Menurut beliau, di dalam diri manusia terdapat tiga macam daya atau potensi, yaitu (a) potensi bernafsu yang disebut al-nafs al-babimiyyat, yang menempati posisi paling rendah; (b) potensi berani yang disebut dengan al-nafs alsabu'iyyat, sebagai potensi pertengahan; dan (c) potensi berpikir yang disebut al-nafs alnathiqah, yang menempati posisi tingkatan potensi tertinggi.

Ketiga daya tersebut merupakan unsur rohani manusia, yang asal kejadiannya berbeda antara satu dengan lainnya. Sebagaimana yang dikutip Heri Gunawan dalam Abuddin Nata, Ibnu Miskawaih dalam bukunya Tahdzib al-Akblak wa Tathbir al-A'raq, memahami bahwa unsur rohani berupa daya bernafsu dan daya berani berasal dari unsur materi, sedangkan daya berpikir berasal dari rub Tuhan. Oleh karena itu, unsur yang

\footnotetext{
16 Ibid., h. 142

17 Ahmad Azhar, Miskawaih..., h. 29-30

${ }^{18}$ Heri Gunawan, Pendidikan Islam ..., h. 309
} 
berasal dari materi akan hancur bersama hancurnya badan, sedangkan unsur yang berasal dari ruh Tuhan tidak akan mengalami kehancuran.

Lebih lanjut Ibnu Miskawaih mengatakan bahwa hubungan daya bernafsu dan daya berani dengan jasad, pada hakikatnya saling mempengaruhi. Kuat atau lemahnya, sehat atau sakitnya kedua macam jiwa tersebut. Kedua macam jiwa ini dalam melaksanakan fungsinya tidak akan sempurna, kalau tidak menggunakan alat bendawi atau badani yang tedapat dalam tubuh manusia. Oleh karena itu, Ibnu Miskawaih melihat bahwa manusia terdiri dari unsur jasad dan rohani yang saling terhubung.

2. Tentang Akhlak

Pemikiran Ibnu Miskawaih dalam bidang akhlak memiliki keunikan dan ciri khas tersendiri. Pemikiran akhlak beliau banyak dipengaruhi oleh para filsuf Yunani, seperti Aristoteles, Plato, dan Galen, yakni meramu pemikiran-pemikiran tersebut dengan ajaran agama Islam. selain itu Ibnu Miskawaih juga dipengaruhi filsuf muslim, seperti Al-Kindi, Al-Farabi, dan Al-Razi, serta filsuf yang lainnya. Oleh karena itu corak pemikiran Ibnu Miskawaih dapat dikategorikan ke dalam tipologi etika filosofi (etika rasional), yaitu pemikiran etika yang banyak dipengaruhi oleh para filsuf.

Karakteristik pemikiran Ibnu Miskawaih dalam pendidikan akhlak secara umum dimulai dengan pembahasan tentang akhlak secara umum dimulai dengan pembahasan tentang akhlak (karakter/watak). Menurut beliau watak itu ada yang bersifat alami ada watak yang diperoleh melalui kebiasaan atau latihan. Kedua watak tersebut pada hakikatnya tidak alami, walaupun kita diciptakan dengan menerima watak, akan tetapi watak tersebut dapat diusahakan melalui pendidikan dan pengajaran.

Adapun pemikiran Ibnu Miskawaih tentang konsep pendidikan akhlak adalah sebagai berikut:

a. Tujuan Pendidikan Akhlak

Ibnu Miskawaih mengatakan bahwa tujuan pendidikan akhlak adalah terwujudnya sikap bathin, yang mampu mendorong secara spontan untuk melahirkan semua perbuatan yang bernilai baik, sehingga mencapai kesempurnaan dan memperoleh kebahagiaan yang sejati dan sempurna. Bahwa kebahagiaan merupakan persoalan utama dan mendasar bagi kehidupan umat manusia dan sekaligus bagi pendidikan akhlak.

b. Tugas Pendidikan Akhlak

Menurut Ibnu Miskawaih, pendidik mempunyai tugas dan tanggung jawab untuk meluruskan peserta didik melalui ilmu rasional, agar mereka dapat mencapai kebahagiaan intelektual dan mengarahkan peserta didik pada disiplin-disiplin praktis, serta aktivitas intelektual, agar dapat mencapai kebahagiaan praktis. Dari pernyataan 
tersebut dapat diketahui bahwa pandangan Ibnu Miskawaih tentang pendidikan sesuai dengan pandangannya tentang jiwa yang ada dalam diri. ${ }^{19}$

c. Tentang metode pendidikan

Terkait dengan metode pendidikan akhlak, menurut Ibnu Miskawaih dalam uapaya mencapai akhlak yang baik, maka seseorang perlu melakukan dua hal utama: pertama, kemauan yang sungguh-sungguh untuk berlatih secara terus-menerus dan menahan diri untuk memperoleh keutamaan dan kesopanan yang sebenarnya adalah sesuai dengan keutamaan jiwa. Kedua, menjadikan pengetahuan dan pengalaman orang lain sebagai cemin bagi dirinya, yaitu pengetahuan dan pengalaman berkenaan dengan hukum akhlak yang berlaku sebagai sebab munculnya kebaikan dan keburukan bagi manusia. Dengan cara ini seseorang tidak akan hanyut kepada perbuatan yang tidak baik, kerena ia bercermin kepada perbuatan buruk dan akibat buruk yang dialami orang lain.

d. Tentang Materi Pendidikan Akhlak

Ibnu Miskawaih mencoba megklasifikasikan materi pendidikan akhlak ke dalam tiga klasifikasi, yaitu: pertama, hal-hal yang wajib bagi kebutuhan tubuh manusia; kedua, hal-hal yang wajib bagi jiwa manusia; dan ketiga, hal-hl yang wajib bagi bagi hubungannya dengan sesama manusia. Pembagian semacam ini tidak terlepas dari pembagiannya tentang daya jiwa manusia. ${ }^{20}$

e. Tentang Lingkungan Pendidikan

Kebahagiaan tidak akan dapat dicapai oleh manusia tanpa bantuan oleh manusia tanpa bantuan orang lain, kebahagiaan bisa dicapai jika manusia bekerja sama, saling tolong menolong dan saling melengkapi. Kondisi tersebut akan tercipta jika sesama manusia saling mencintai. Menurut Ibnu Miskawaih, sebaik-baik manusia adalah orang yang berbuat baik terhadap keluarga dan orang-orang yang masih ada hubungan dengan saudara, anak atau orang yang memiliki hubungan dengan saudara, kerabat, keturuanan, rekan, tetangga, dan lain sebagainya. Salah satu tabiat manusia adalah memelihara diri. Untuk memperolehnya, maka manusia harus berusaha dan memperolehnya secara bersama-sama dengan makhluk sejenisnya, diantaranya adalah dengan cara melakukan pertemuan; seperti shalat berjamaah. Ibnu Miskawaih tidak membicarakan secara eksplisit tentang lingkungan pendidikan, tetapi beliau banyak membicarakan tentang lingkungan masyarakat secara umum.

\footnotetext{
${ }^{19}$ Ibid., h. 311

${ }^{20}$ Ibid., h. 312
} 


\section{f. Tentang Konsep Pembelajaran}

Menurut Ibnu Miskawaih, pembelajaran itu tidak akan berjalan dalam jalannya yang benar, kecuali jika memperhatikan berbagai prinsip dasar: pertama, memperhatikan persiapan, perbedaan individu yang berbeda diantara para individu manusia; kedua, menjaga keseimbangan perilaku siswa dalam aturan yang bersifat khusus, yang disesuaikan dengan perkembangan anak baik dari segi psikis (jiwa) maupun fisiknya. ${ }^{21}$

Dari pemaparan diatas, konsep pemikiran pendidikan Islam Ibnu Miskawaih adalah tentang pendidikan akhlak, dimana akhlak merupakan karakter yang menetap di dalam jiwa, dipertahankan dengan penjagaan dari hal-hal yang bisa merusak akhlak. Dari akhlak yang telah dijiwai dalam diri manusia kemudia diaktualkan melalui perbuatan-perbuatan yang mencerminkan akhlak yang baik. Dapat dikatakan akhlak yang baik apabila akhlak dalam hati dan akhlak dalam konteks perbuatan itu sesuai. Akhlak tercipta dari pembawaan manusia itu sendiri dan juga bisa tercipta dari pendidikan, pengajaran dan pengalaman yang dialami. Pertama, Akhlak yang bertolak dari pembawaan, misalnya ada orang yang gampang marah karena hal yang sepele, takut menghadapi suatu kejadian tertentu, cemas, dan sebagainya. Kedua, akhlak yang tercipta melalui kebiasaan dan latihan yang pada mulanya keadaan ini terjadi karena dipertimbangkan dan dipikirkan, namun kemudian melalui praktik yang terusmenerus kemudian menjadi karakter.

\section{Relevansi Pemikiran Pendidikan Ibnu Miskawaih di Era Modern}

Pendidikan pada abad modern ini, posisi peserta ditempatkan pada posisi utama dalam kepedulian tugas-tugas pendidikan, dimana sistem pendidikan harus didasarkan pada ilmuilmu yang membicarakan kepribadian peserta didik. Seperti diketahui peserta didik mudah terpengaruh oleh hal-hal yang dilihatnya, dan juga oleh buku-buku yang dibacanya. Dengan kata lain, seorang anak mudah terpengaruh contoh-contoh dan suka meniru hal-hal yang konkret. $^{22}$

Etika seyogyanya diajarkan pada remaja semenjak kecil, meliputi etika makan, minum, berpakaian, berjalan, berkendaraan, berolah raga, tidur, berjalan, bermasyarakat dan lainnya. ${ }^{23}$ Ibnu Miskawaih juga mengatakan nasehat-nasehat yang berkenaan dengan ilmu kesehatan, makanan yang sehat dan lain-lain. Tidak ada larangan dalam hal penganekaragaman

\footnotetext{
21 Ibid., h. 313

22 Syamsudin Asyrofi, Beberapa Pemikiran Pendidikan, (Malang: Aditya Media, 2012), h 40-41

${ }^{23}$ Sudin, Filosof Etika dan Sosial Islam Ibn Miskawaih, (Yogyakarta: SUKA-Press, 2012), h 9
} 
pendidikan, disesuaikan dengan keaneka ragaman pendidikan itu mengikuti petunjuk syari'ah dan akal sehat untu mencapai kebahagiaan yang sempurna. ${ }^{24}$

Salah satu dari karya Ibnu Miskawaih yang memuat pemikiran pendidikannya adalah termuat dalam bukunya Tahrib al-Akblak (Pendidikan Akhlak). Menurut pandangannya manusia adalah makluk yang memiliki keistimewaan karena dalam kenyataan manusia memiliki daya pikir. Berdasarkan daya pikir itu pula manusia dapat membedakakan antara yang benar dan yang salah, serta yang baik dan yang buruk. Manusia yang paling sempurna penciptaannya adalah merek yang paling benar cara berfikirnya serta yang paling mulia usaha dan perbuatannya.

Dalam konteks ini Ibnu Miskawaih menekankan kerjasama yang merupakan penopang utama dalam kegiatan manusia untuk mencapai kebahagiaan dan kesempurnaan sifat-sifat kemanusiaannya sejalan dengan hakikat pencitaannya. Di sini terlihat kecenderungan Ibnu Miskawaih menempatkan akhlak sebagai dasar pemikiran pendidikannya. ${ }^{25}$ Sedangkan mengenai susunan yang akan diajarkan kepada perserta didik, Ibnu Miskawaih memandang bahwa pendidikan akhlak harus ditanamkan mulai dari anak usia dini karena perkembangan mental anak masih berevolusi sehingga berkembang sampai menuju kesempurnaan untuk menyimpan pesan-pesan yang sangat baik dan merasuk kedalam jiwa berpikir.

Oleh karenanya pendidikan bukan semata-mata untuk mempelajari ilmu pengetahuan tetapi lebih jauh untuk mengkaji secara mendalam tentang seberapa pengaruh antara ilmu pengetahuan terhadap etika dan akhlak masyarakat. Pertama adalah kita harus mengenalkan bagaimana kewajiban-kewajiban syariat kepada peserta didik agar mereka terbiasa melaksanakannya. Kedua materi yang berhubungan dengan akhlak perlu diberi contoh agar akhlak terpuji yang di tertanamkan kepada anak bisa tercapai dengan baik. Ketiga yaitu meningkatkan setahap demi setahap pada materi ilmu yang lain sehingga peserta didik mencapai tingkat kemampuan yang sempurna.

Manusia mempunyai perbedaan dalam menerima pendidikan. Ada juga yang kasar, ada yang pemalu, pemarah, dengki, kikir, lemah lembut, ada yang cepat tanggap, ada yang tidak tanggap dan lain semacamnya. Perbedaan-perbedaan (tabiat) ini kalau diabaikan maka dia akan berkembang secara alamiah sesuai dengan tabiat yang dimilikinya. Maka dari itu beliau memandang pentingnya suatu pendidikan (syariat agama) untuk meluruskan agar terbiasa melakukan kebaikan. Karena pendidikan mempunyai tujuan dan fungsi yaitu: memanusiakan

\footnotetext{
${ }^{24}$ Ibid., h. 11

25 Jalaluddin dan Usman Said, Filsafat Pendidikan Islam; Konsep dan Perkembangan Pemikirannya, Jakarta: RajaGrafindo, 1999), h. 134-135

26
} 
manusia atau menundukkan manusia sesuai dengan substansinya sebagai makhluk yang termulia dari makhluk lain. ${ }^{26}$

Adapun sisi yang perlu dikembangkan dari gagasan Ibnu Miskawaih walau bagaimanapun juga pendidikan hendaknya tidak mengenyampingkan pendidikan moral. Kalau kita mencoba bercermin dari krisis ekonomi yang baru ini melanda bangsa kita sebetulnya diawali oleh krisis moral, di mana penyelenggaraan pendidikan hanya beroreintasi pada persaingan ekonomi global, sementara garapan moral sebagai pengejawantahan agama kurang mendapat perhatian seakan-akan hanya sebatas pengajaran materi sebagai pelengkap bukan penanaman pendidikan moral yang mengarah kepada kedewasaan dan tanggung jawab, atau dengan kata lain pendidikan hanya menunjukkan "learning for knowledge" tidak "learning to be person". ${ }^{27}$

Menurut Ibnu Miskawaih bahwa masalah pokok kajian akhlak adalah kebaikan dan kebahagiaan. Pembahasan ini memiliki kaitan erat dengan pembahasan akhlak. Menurut Ibnu Miskawaih, kebaikan diartikan sebagai tujuan setiap sesuatu. Jadi, kebaikan berarti tujuan terakhir. Sementara kebahagiaan diartikan sebagai kebaikan dalam kaitannya dengan pemiliknya dan kesempurnaan bagi pemiliknya. Dengan kata lain, kebahagian itu bagian dari kebaikan. Secara agak mendalam, maka kebahagiaan dapat diartikan sebagai kesempurnaan dan akhir dari kebaikan. Kebahagiaan merupakan kebaikan paling utama di antara seluruh kebaikan lainnya. ${ }^{28}$

Krisis pendidikan di manapun selalu sepadan intensitasnya dengan krisis yang melanda masyarakatnya. Dimensi-dimensi sosial-kultural mengalami perubahan dan pergeseran dalam nilai-nilai, disebabkan oleh sumber-sumber kekuatan baru yang memengaruhi. Pada masa modern ini, masyarakat manusia sedang berada di dalam krisis itu akibat pengaruh dari kekuatan ilmu dan teknologi modern yang melaju dengan cepatnya. ${ }^{29}$

Ketika kita membicarakan pendidikan Islam dan tantangannya di masa modern ini, sangatlah penting menyebutkan tujuh karakteristik yang dimiliki pendidikan Islam, yaitu: (1) Penguasaan ilmu pengetahuan, bahwa ajaran dasar Islam mewajibkan pemeluknya mencari ilmu pengetahuan, (2) Pengembangan ilmu pengetahuan, yaitu ilmu yang telah dikuasai harus diberikan dan dikembangkan kepada orang lain, (3) Penekanan pada nilai-nilai akhlak dalam penguasaan dan pengembangan ilmu pengetahuan, (4) Dasar beribadah kepada Allah dan

26 Ahmad Wahyu Hidayat \& Ulfa Kesuma, “Analisis Filosufis Pemikiran Ibnu Miskawaih" Jurnal Pendidikan Islam 2, no 1, (2019), h. 96-97

27 Ibid., h. 99

${ }^{28}$ Hadis Purba, "Pemikiran Pendidikan Islam Ibnu Miskawaih", MIQOT XXXIII, no. 2, (Juli-Desember 2009), h. 268

${ }^{29}$ Haidar Putra Daulay, Pendidikan Islam ..., h. 96 
kemashlahatan umum, (5) Memperhatikan perkembangan anak didik, (6) Pengembangan kepribadian Islam, (7) Penekanan pada amal saleh dan tanggung jawab sosial. ${ }^{30}$

Lembaga pendidikan Islam di Indonesia dalam menjawab tantangan di era modern tidak boleh kehilangan esensi religiusitas atau keislamannya. Harus selalu berbenah dan memegang prinsip pendidikan sebagai wahana humanisasi tanpa mengorbankan nilai-nilai kemanusiaan. Pendidikan sebagai investasi jangka panjang dalam pembangunan bangsa harus menghindarkan dampak negatif yang ditimbulkan di era modern ini. Langkah awal yang dilakukan adalah pembenahan akhlak yang mengalami kemrosotan, sebagaimana yang dirasakan Ibnu Miskawaih pada zamannnya.

Peranan minimal agama dalam pengembangan ilmu pengetahuan dan teknologi di era modern ini adalah memberikan makna kemanusiaan yang menuntut kebersamaan tenggung jawab dalam mengelola bumi agar lestari. Proses kesesuaiann antar agama dan pemikiran (religious-rasional) harus di langsungkan terus menerus untuk membangun struktur dan kultur kehidupan stabil dan damai yang bersendikan iman dan taqwa kepada Tuhan di era modern ini.

Relevansi pemikiran pendidikan Islam Ibnu Miskwaih di era modern ini adalah bahwa pendidikan akhlak harus selalu di pegang teguh oleh pendidik dan peserta didik guna menghadapi segala tuntutan di era modern ini. Melalui potensi rasional yang dapat membedakn mana yang baik dan yang buruk melalui pendidikan, pengajaran dan pengalaman maka pondasi akhlak yang baik dan mulia dapat tercipta. Berangkat dari akhlak yang baik kepada Tuhan, alam semesta dan sesama manusia, diharapkan akan melahirkan manusiamanusia modern dengan segala kemajuannya yang lebih peduli terhadap sesama, tidak hanya mementingkan keuntungan pribadi saja.

\section{SIMPULAN}

Ibnu Miskawaih adalah serang ahli sejarah yang pemikirannya sangat cemerlang, beliaulah ilmuwan Islam yang paling terkenal dan yang pertama kali menulis filsafat akhlak. Pengetahuan Ibnu Miskawaih yang amat menonjol dari hasil banyak membaca buku itu ialah tentang sejarah, filsafat dan sastra. Hingga saat ini nama Ibnu Miskawaih dikenal terutama sekali dalam keahliannya sebagai sejarawan dan filsuf. Sebagai filsuf, Ibnu Miskawaih memperoleh sebutan Bapak Etika Islam.

Sebagai seorang filsuf akhlak, pemikiran Ibnu Miskawaih dalam pendidikan tidak bisa dilepaskan dari konsep tentang manusia dan akhlak. Karakteristik pemikiran Ibnu Miskawaih dalam pendidikan akhlak secara umum dimulai dengan pembahasan tentang akhlak secara

${ }^{30}$ Ibid., h. 101 
umum dimulai dengan pembahasan tentang akhlak (karakter/watak). Menurut beliau watak itu ada yang bersifat alami ada watak yang diperoleh melalui kebiasaan atau latihan.

Relevansi pemikiran pendidikan Islam Ibnu Miskwaih di era modern ini adalah bahwa pendidikan akhlak harus selalu di pegang teguh oleh pendidik dan peserta didik guna menghadapi segala tuntutan di era modern ini. Berangkat dari akhlak yang baik kepada Tuhan, alam semesta dan sesama manusia, diharapkan akan melahirkan manusia-manusia modern dengan segala kemajuannya yang lebih peduli terhadap sesama, tidak hanya mementingkan keuntungan pribadi saja.

\section{DAFTAR PUSTAKA}

Basyir, A. A. Miskawaih Riwayat Hidup dan Pemikiran Filsafatnya. Yogyakarta: Nur Cahaya, 1983.

Hidayat, A. W. dan Ulfa Kesuma. “Analisis Filosufis Pemikiran Ibnu Miskawaih”. Jurnal Pendidikean Islam 2, no. 1, 2019.

Pratama, D. A. N. "Tantangan Karakter Di Era Revolusi Industri 4.0 Dalam Membentuk Kepribadian Muslim”. Al-Tanzim: Jurnal Manajemen Pendidikan Islam 03, no.01.

Rahman, F. Islam and Modernity, Transformasi of an Intellectual Tradition. Pustaka: Bandung, 1985.

Purba, H. Pemikiran Pendidikan Islam Ibnu Miskawaih. MIQOT XXXIII, no. 2 (JuliDesember 2009).

Daulay, H. P. Pendidikan Islam dalam Perspektif Filsafat. Jakarta: Kencana, 2014.

Langgulung, H. Asas-Asas Pendidikan Islam. Jakarta: PT Al Husna Zikra, 2000.

Gunawan, H. Pendidikan Islam Kajian Teoritis dan Pemikiran Tokoh. Bandung: Remaja Rosdakarya, 2014.

Sirat, I, Dja'far S, Siti Z. "Implementasi Pendidikan Akhlak Dalam Pengembangan Pendidikan Karakter Di Man 1 Medan”. Jurnal Edu Religia 1, no.4 (Desember 2017).

Jalaluddin dan Usman S. Filsafat Pendidikan Islam; Konsep dan Perkembangan Pemikirannya. Jakarta: RajaGrafindo, 1999.

Maimun, Menjadi Guru Yang Di rindukan (Pelita Yang Menerangi Jalan Hidup Siswa). Yogyakarta: Kurnia Kalam Semesta, 2014.

Rusmaini. "Manajemen Pendidikan Karakter di Lembaga Pendidikan Islam". Jurnal Of Islamic Education Management 3, no.1 (Juni 2017)

Sudin. Filosof Etika dan Sosial Islam Ibn Miskawaih. Yogyakarta: SUKA-Press, 2012. 
Jurnal Penelitian Keislaman Vol.16 No.1 (2020): 16-30

Asyrofi, S. Beberapa Pemikiran Pendidikan. Malang: Aditya Media, 2012.

Usman. Filsafat Pendidikan Kajian Filosofi: Pendidikan Nabdlatul Wathan di Lombok. Yogyakarta: Teras, 2012. 